\title{
PENGARUH KUALITAS PRODUK, CITRA MEREK DAN WORD OF MOUTH TERHADAP MINAT BELI ULANG MELALUI KEPUASAN KONSUMEN PADA MAHASISWA ESA UNGGUL PENGGUNA IPHONE
}

\author{
Sugiyanto $^{1 *}$, Edo Maryanto $^{2}$ \\ 1,2 Universitas Esa Unggul \\ *Email: sugiyanto@esaunggul.ac.id
}

\begin{abstract}
Abstrak
Tujuan penelitian ini adalah untuk mengetahui pengaruh kualitas produk, citra merek dan word of mouth terhadap minat beli ulang melalui kepuasan konsumen pada Mahasiswa Esa Unggul Pengguna Iphone. Penelitian ini berjenis penelitian kuantitatif dengan jenis penelitian assosiatif kausal. Populasi dalam penelitian ini mahasiswa aktif regular dan paralel Universitas Esa Unggul fakultas Ekonomi di Citra Raya sebanyak 170 orang yang diambil dengan meggunakan metode purposive sampling. Pengujian data dilakukan dnega menggunakan metode uji validitas, uji realibiltas, dan Analisis Jalur. Berdasarkan hasil penelitian dapat ditarik beberapa kesimpulan sebagai berikut: 1) Variabel Kualitas Produk, Citra Merek, Word of Mouth, berpengaruh positif dan signifikan terhadap kepuasan konsumen pada mahasiswa fakultas ekonomi Universitas Esa Unggul; 2) Variabel Kualitas Produk, Citra Merek, Word of Mouth, dan Kepuasan Konsumen berpengaruh positif dan signifikan terhadap minat beli ulang pada mahasiswa fakultas ekonomi Universitas Esa Unggul; 3) Variabel Kualitas Produk dan Citra Merek mempunyai pengaruh positif dan signifikan terhadap minat beli ulang tetapi kepuasan konsumen tidak memediasi; dan 4) Variabel Word of Mouth mempunyai pengaruh positif dan signifikan terhadap minat beli ulang dengan mediasi kepuasan konsumen.
\end{abstract}

Kata Kunci: Kualias Produk, Citra Merek, Word of Mouth, Minat Beli Ulang.

\begin{abstract}
The purpose of this study was to determine the effect of product quality, brand image and word of mouth on repurchase interest through consumer satisfaction in Esa Unggul Student Iphone users. This type of research is quantitative research with causal associative research. The population in this study were 170 regular and parallel active students at Esa Unggul University, Faculty of Economics, Citra Raya, which were taken using the purposive sampling method. Data testing was carried out using the validity test, reliability test, and path analysis methods. Based on the results of the study, several conclusions can be drawn as follows: 1) Product Quality, Brand Image, Word of Mouth variables have a positive and significant effect on consumer satisfaction in students of the economics faculty of Esa Unggul University; 2) Variables of Product Quality, Brand Image, Word of Mouth, and Consumer Satisfaction have a positive and significant effect on repurchase interest in students of the economics faculty of Esa Unggul University; 3) Product Quality and Brand Image variables have a positive and significant influence on repurchase intention but consumer satisfaction does not mediate; and 4) Word of Mouth variable has a positive and significant effect on repurchase intention by mediating consumer satisfaction.
\end{abstract}

Keywords: Product Quality, Brand Image, Word of Mouth, Repurchase Interest. 


\section{A. PENDAHULUAN}

Seiring berkembangnya ilmu pengetahuan dan teknologi saat ini membuat komunikasi semakin canggih dan menjadi serba mudah. Para pelaku bisnis produk komunikasi berlombalomba untuk dapat menarik perhatian konsumen agar menggunakan dan berminat untuk membeli produknya. Persaingan yang semakin ketat dan kompetitif membuat pelaku pasar lebih berpacu dan bersaing untuk dapat bertahan dalam dunia bisnis karena para pelaku pasar atau pesaing bukan hanya ada di dalam negeri saja tetapi ada juga di luar negeri. Pemasar merupakan salah satu kunci suksesnya perusahaan dalam mempertahankan perusahaannya pada persaingan di dunia bisnis saat ini. Kesuksesan perusahaan dapat dilihat dari peningkatan jumlah produksi hingga proses pemasarannya, maka dari itu perusahaan haruslah memiliki produk yang baik untuk diproduksi dan dipasarkan. Untuk itu perusahaan juga harus memikirkan strategi yang baik dan semaksimal mungkin untuk dapat merebut pangsa pasar dan meningkatkan volume penjualan.

Berdasarkan data, pada akhir kuartal tahun 2017 iPhone masih unggul walaupun hanya sedikit di atas Samsung dengan 19,60\%. Sementara pada kuartal pertama ditahun 2018, Samsung menguasai pangsa pasar cukup signifikan sebesar 23,50\%. Untuk kuartal kedua sampai dan kuartal empat, Samsung tetap menguasai pasar meskipun terjadi penurunan sedikit demi sedikit. Sementara iPhone mengalami penurunan pada awal kuartal pertama sampai ketiga dan mengalami kenaikan pada kuartal ke empat yang signifikan sebesar 5,10\%. Tak bertahan lama, pada kuartal pertama ditahun 2019, iPhone mengalamai penurunan yang cukup jauh sebesar 6,50\% sementara Samsung berbanding terbalik mengalami kenaikan sebesar 4,20\% (International Data Corporation, 2019). Untuk produk smartphone lain tidak mengalami atau kenaikan yang signifikan.

Kepuasan konsumen merupakan sejauh mana tingkatan produk dipersepsikan sesuai dengan harapan pembeli (Amstrong \& Keller, 2015). Jika produk tersebut jauh di bawah harapan, maka konsumen akan kecewa. Sebaliknya jika produk tersebut memenuhi harapan, maka konsumen akan puas. Harapan konsumen dapat diketahui dari pengalaman mereka sendiri saat menggunakan produk, informasi dari orang lain, dan informasi dari iklan atau promosi.

Word of Mouth marketing adalah usaha pemasaran yang memicu konsumen untuk membicarakan, mempromosikan, merekomendasikan dan menjual produk atau merek kepada konsumen lain (Phillip Kotler \& Keller, 2009). Word of Mouth merupakan salah satu bentuk promosi yang dilakukan konsumen untuk menyampaikan dan menginformasikan kepada konsumen lain tentang pengalaman mereka setelah mengkonsumsi atau menggunakan suatu produk atau jasa. Proses Word of Mouth ini sering terjadi karena setiap harinya orang-orang saling berbicara, dimana saling bertukar pikiran, saling tukar pendapat, saling berkomentar, saling tukar informasi dan proses komunikasi lainnya.

Penelitian ini berkaitan dengan kualitas prdouk, citra merek dan Word of Mouth terhadap minat beli ulang melalui kepuasan sebagai variabel intervening. (Puspasari, 2014) telah melakukan penelitian dan menemukan bahwa kualitas produk berpengaruh positif dan signifikan terhadap minat beli ulang, Hasil Penelitian yang berbeda ditemukan dalam penelitian (Palma \& Andjarwati, 2016) dalam penelitiannya tersebut kualitas produk tidak berpengaruh signifikan terhadap niat beli ulang. Hasil yang negatif juga ditemukan pada penelitian yang dilakukan oleh (Denniswara, 2016), dalam penelitian tersebut kualitas produk tidak berpengaruh signifikan terhadap intensi membeli ulang. Hasil penelitian lainnya yang dilakukan oleh (Prastiwi, 2016), dalam penelitiannya tersebut bahwa kepuasan tidak berpengaruh signifikan terhadap niat membeli ulang. 


\section{B. TINJAUAN PUSTAKA}

\section{Kualitas Produk}

Menurut Kotler \& Keller, (2014) kualitas produk adalah karakter yang dimiliki sebuah produk yang memiliki kemampuan untuk memenuhi kebutuhan pelanggan. Kotler \& Armstrong dalam (Lenzun et al., 2014) menyatakan arti dari kualitas produk adalah kemampuan sebuah produk dalam memperagakan fungsinya, hal itu termasuk keseluruhan durabilitas, reliabilitas, ketepatan, kemudahan pengoperasian dan reparasi produk juga atribut produk lainnya.

Tjiptono, (2015) mengemukakan bahwa definisi konvensional dari kualitas adalah sebagai gambaran langsung dari suatu produk seperti performasi, keandalan, mudah dalam penggunaan estetika dan sebagainya. Dalam definisi stratejik, kualitas adalah segala sesuatu yang mampu memenuhhi keinginan atau kebutuhan pelanggan (meeting the needs of customer). Kualitas produk merupakan faktor penentu kepuasan konsumen setelah melakukan pembelian dan pemakaian terhadap suatu produk. Produk dengan kualitas prima akan lebih menarik bagi konsumen, lebih mencari kualitas dalam membeli produk yang dibutuhkan sehingga penting bagi perusahaan untuk meningkatkan kualitas yang lebih berorientasi pada konsumen. Dapat disimpulkan bahwa kualitas produk adalah kondisi nyata dari sebuah produk yang diproduksi oleh perusahaan, produk yang berkualitas adalah produk yang telah memenuhi standar dan kualifikasinya dan yang bisa digunakan sesuai dengan fungsinya. Sehingga dapat diajukan hipotesis sebagai berikut:

H1: Diduga terdapat pengaruh positif kualitas produk terhadap kepuasan konsumen pada mahasiswa fakultas ekonomi pengguna iPhone.

H4: Diduga terdapat pengaruh positif kualitas produk terhadap minat beli ulang pada mahasiswa fakultas ekonomi pengguna iPhone.

H8: Diduga terdapat pengaruh positif kualitas produk terhadap minat beli ulang melalui kepuasan konsumen pada mahasiswa fakultas ekonomi pengguna iPhone.

\section{Citra Merek}

Philip Kotler \& Amstrong, (2014) menyatakan bahwa citra merek adalah sekumpulan keyakinan terhadap suatu merek disebut citra merek. Citra merek yang kuat dapat memberikan beberapa keunggulan utama bagi suatu perusahaan salah satunya akan menciptakan suatu keunggulan bersaing. Citra merek adalah apa yang dipersepsikan oleh konsumen mengenai sebuah merek. Seorang konsumen menggambarkan apa yang mereka pikirkan mengenai sebuah merek dan apa yang mereka rasakan mengenai merek tersebut ketika mereka memikirkannya (Sinurat et al., 2017). Sedangkan menurut (Hasan, 2014) mendefinisikan citra merk atau Brand Image merupakan sifat tangible dan intangible seperti ide, keyakinan, nilainilai, kepentingan, dan fitur yang membuat suatu merk menjadi unik. Bila disimpulkan dari definisi diatas, maka citra merk atau brand image adalah sifat merek yang membuat suatu merk menjadi unik yang ada dalam ingatan konsumen.

Citra merek umumnya didefinisikan segala hal yang terkait dengan merek yang ada dibenak ingatan konsumen. Hal tersebut menunjukan bahwa citra merek produk merupakan asset perusahaan dalam melanjutkan pemasaran suatu produk yang akan memberikan pengaruh terhadap loyalitas konsumen terhadap produk. Dapat disimpulkan bahwa citra merek adalah suatu identitas produk yang dapat membedakan setiap produk dengan produk lainnya dengan cara menautkan kepada konsumen sehingga dapat tertanam pada benak konsumen. Faktorfaktor yang menjadi pembentuk citra merek menurut Fajrianthi dalam Tanoni dalam (Waskita \& Yuniati, 2016), adalah sebagai berikut: Kualitas atau mutu, dapat dipercaya atau diandalkan, kegunaan atau manfaat, kelayanan, resiko, harga, citra yang dimiliki oleh merek itu sendiri.

Menurut Hoeffler dan Keller dalam Pujadi, (2010) dimensi dari citra merek (brand image) adalah: 1) Kesan profesional; 2) Kesan modern; 3) Melayani semua segmen produk 
mampu melayani semua segmen yang ada, tidak hanya melayani segmen khusus saja; dan 4) Perhatian pada konsumen dalam suatu produk harus perhatian. Sehingga dapat diajukan hipotesis sebagai berikut:

H2: Diduga terdapat pengaruh positif citra merek terhadap kepuasan konsumen pada mahasiswa fakultas ekonomi pengguna iPhone.

H5: Diduga terdapat pengaruh positif citra merek terhadap minat beli ulang pada mahasiswa fakultas ekonomi pengguna iPhone.

H9: Diduga terdapat pengaruh positif citra merek terhadap minat beli ulang melalui kepuasan konsumen pada mahasiswa fakultas ekonomi pengguna iPhone.

\section{Word of Mouth}

Komunikasi dari mulut ke mulut (Word of Mouth) ini merupakan salah satu saluran komunikasi yang sering digunakan oleh perusahaan. Komunikasi ini dinilai sangat efektif dan tidak butuh mengeluarkan biaya dalam memperlancar proses pemasaran dan mampu memberikan keuntungan kepada perusahaan pelanggan seringkali terlibat secara langsung dalam menyampaikan kepada pelanggan potensial lain tentang pengalaman mereka di dalam mengkonsumsi suatu produk ataupun jasa. Ada beberapa definisi menurut para ahli, sebagai berikut.

Philip Kotler \& Keller, (2007) mengemukakan bahwa Word of Mouth (WOM) atau komunikasi dari mulut ke mulut merupakan proses komunikasi yang berupa perpindahan informasibaik secara individu maupun kelompok terhadap suatu produk atau jasa yang bertujuan untuk memberikan informasi secara personal. Komunikasi dari mulut ke mulut merupakan salah satu saluran komunikasi yang sering digunakan oleh perusahaan yang memproduksi baik barang maupun jasa karena komunikasi dan mulut ke mulut (Word of Mouth) dinilai sangat efektif dalam memperlancar proses pemasaran dan mampu memberikan keuntungan kepada perusahaan.

Menurut Bickart \& Schindler dalam Sari, (2016) komunikasi Word of Mouth biasanya terdiri dari kata-kata yang diucapkan dan dipertukarkan dengan salah sorang teman atau kerabat dalam situasi tatap muka. Sedangkan menurut Jalilvand dalam (Aghniyah, 2019) Word of Mouth memiliki peran penting di dalam mempengaruhi pembentukan sikap dan perilaku konsumen. Sehingga dapat diajukan hipotesis sebagai berikut:

H3: Diduga terdapat pengaruh positif Word of Mouth terhadap kepuasan konsumen pada mahasiswa fakultas ekonomi pengguna iPhone

H6: Diduga terdapat pengaruh positif Word of Mouth terhadap minat beli ulang pada mahasiswa fakultas ekonomi pengguna iPhone

H7: Diduga terdapat pengaruh positif kepuasan konsumen terhadap minat beli ulang pada mahasiswa fakultas ekonomi pengguna iPhone

H10: Diduga terdapat pengaruh positif Word of Mouth terhadap minat beli ulang melalui kepuasan konsumen pada mahasiswa fakultas ekonomi pengguna iPhone.

\section{METODE}

Penelitian ini berjenis penelitian kuantitatif. Penelitian ini menggunakan jenis penelitian assosiatif kausal yang menjelaskan bahwa variable independen (X) mempengaruhi variable dependen (Y). Variabel dalam penelitian ini antara lain Kualitas Produk $\left(\mathrm{X}_{1}\right)$, Citra merek $\left(\mathrm{X}_{2}\right)$, Word of Mouth $\left(\mathrm{X}_{3}\right)$, Minat beli ulang $(\mathrm{Y})$ dan Kepuasan Konsumen (Z). Jenis data yang digunakan dalam peneltian ini adalah data primer dan data sekunder. Populasi dalam penelitian ini mahasiswa aktif regular dan paralel Universitas Esa Unggul fakultas Ekonomi di Citra Raya sebanyak 170 orang yang diambil dengan meggunakan metode purposive sampling. Ukuran skala yang digunakan dalam peneltian ini adalah skala likert. Pengujian data dilakukan dnega menggunakan metode uji validitas, uji realibiltas, dan Analisis Jalur. 


\section{HASIL DAN PEMBAHASAN}

\section{Karakteristik Responden Penelitian}

Pada penelitian ini dilakukan analisis terhadap mahasiswa fakultas ekonomi Universitas Esa Unggul sebanyak 119 orang. Adapun data yang diteliti sebagai berikut:

\section{Tabel 1. Responden Penelitian}

\begin{tabular}{|c|c|c|c|}
\hline \multicolumn{2}{|c|}{ Keterangan } & Jumlah & Persentase \\
\hline \multirow{2}{*}{ Jenis Kelamin } & Laki-Laki & 47 & $39,5 \%$ \\
\cline { 2 - 4 } & Perempuan & 72 & $60,5 \%$ \\
\hline \multirow{3}{*}{ Usia } & $17-23$ tahun & 90 & $75,6 \%$ \\
\cline { 2 - 4 } & $24-35$ tahun & 25 & $21 \%$ \\
\cline { 2 - 4 } & $>36$ tahun & 4 & $3,4 \%$ \\
\hline \multirow{2}{*}{ Domisili } & Tangerang & 100 & $84 \%$ \\
\cline { 2 - 4 } & Luar Tangerang & 19 & $16 \%$ \\
\hline \multirow{2}{*}{ Status } & Menikah & 104 & $87,4 \%$ \\
\cline { 2 - 4 } & Belum Menikah & 15 & $12,6 \%$ \\
\hline \multirow{3}{*}{$\begin{array}{c}\text { Lama } \\
\text { IPhogunakan }\end{array}$} & 1 tahun & 52 & $21,7 \%$ \\
\cline { 2 - 4 } & $>1$ tahun -2 tahun & 26 & $31,5 \%$ \\
\cline { 2 - 4 } & $>2$ tahun & 41 & \\
\hline
\end{tabular}

Sumber: Data Diolah

Berdasarkan table 1 diatas, mahasiswa fakultas ekonomi Universitas Esa Unggul lebih dominan yang berjenis kelamin perempuan dengan presentase sebesar 60,5\% dengan jumlah responden sebanyak 72 orang. Sehingga dapat disimpulkan bahwa seorang perempuan memiliki minat yang tinggi untuk menempuh pendidikan sarjana. Selanjutnya, dari segi usia mahasiswa fakultas ekonomi Universitas Esa Unggul lebih dominan berusia 17-23 tahun dengan presentase $75,6 \%$ dengan jumlah responden 90 orang. Dengan hasil yang ada maka dapat disimpulkan mahasiswa disana memiliki usia yang sudah bisa memiliki tanggung jawab dalam menentukan pilihan.

Dari segi domisili, mahasiswa fakultas ekonomi Universitas Esa Unggul lebih dominan responden yang berdomisili di Tangerang yaitu sebanyak 100 responden dengan presentase 84\% sehingga berdasarkan data yang ada dapat disimpulkan bahwa mahasiswa fakultas ekonomi Universitas Esa Unggul berdomisili di Tangerang sehingga mempermudah untuk melakukan penelitian. Sedangkan dari segi status, mahasiswa fakultas ekonomi Universitas Esa Unggul lebih dominan responden yang belum menikah dengan jumlah responden 104 orang dan presentase $87,4 \%$. Hal ini menunjukkan bahwa mahasiswa yang belum menikah belum memiliki tanggung jawab berupa beban ekonomi keluarga sehingga bisa mempergunakan uang untuk keperluan pribadi.

Berdasarkan lama waktu menggunaka Iphone, mahasiswa fakultas ekonomi Universitas Esa Unggul lebih dominan mahasiswa yang sudah menggunakan IPhone jangka waktu 1 tahun dengan jumlah 52 responden dan presentase 43,7\%. Maka berdasarkan data yang ada dapat disimpulkan bahwa mahasiswa fakultas ekonomi Universitas Esa Unggul dikategorikan merupakan pelanggan IPhone yang setia.

\section{Uji Validitas}

Uji validitas dalam penelitian ini digunakan analisis item, yaitu mengkorelasikan skor tiap butir dengan skor total yang merupakan jumlah dari tiap skor butir. Jika ada item yang tidak memenuhi syarat, maka item tersebut tidak akan diteliti lebih lanjut. Uji validitas yang akan digunakan adalah validnya sebuah item pernyataan dalam kuesioner dengan jumlah responden atau jumlah data sebanyak 30 . Berdasarkan kriteria dengan ketentuan df yang sudah didapat ( $\mathrm{df}=28$ dengan sig 5\%) dapat disimpulkan bahwa nilai $\mathrm{r}$ tabel adalah sebesar 0,361. Hasil pengujian validitas dalam penelitian ini disajikan dalam tabel berikut: 
ARTIKEL

Tabel 2. Hasil Uji Validitas

\begin{tabular}{|c|c|c|c|}
\hline \multicolumn{2}{|c|}{ Pertanyaan } & Nilai $\mathbf{r}$ hitung & Keterangan \\
\hline \multirow{16}{*}{$\mathrm{X} 1$} & 1 & 0,531 & Valid \\
\hline & 2 & 0,531 & Valid \\
\hline & 3 & 0,478 & Valid \\
\hline & 4 & 0,120 & Valid \\
\hline & 5 & 0,446 & Valid \\
\hline & 6 & 0,715 & Valid \\
\hline & 7 & 0,619 & Valid \\
\hline & 8 & 0,571 & Valid \\
\hline & 9 & 0,288 & Valid \\
\hline & 10 & 0,463 & Valid \\
\hline & 11 & 0,531 & Valid \\
\hline & 12 & 0,559 & Valid \\
\hline & 13 & 0,553 & Valid \\
\hline & 14 & 0,678 & Valid \\
\hline & 15 & 0,561 & Valid \\
\hline & 16 & 0,770 & Valid \\
\hline \multirow{8}{*}{$\mathrm{X} 2$} & 1 & 0,616 & Valid \\
\hline & 2 & 0,547 & Valid \\
\hline & 3 & 0,693 & Valid \\
\hline & 4 & 0,690 & Valid \\
\hline & 5 & 0,678 & Valid \\
\hline & 6 & 0,576 & Valid \\
\hline & 7 & 0,590 & Valid \\
\hline & 8 & 0,380 & Valid \\
\hline \multirow{10}{*}{ X3 } & 1 & 0,720 & Valid \\
\hline & 2 & 0,701 & Valid \\
\hline & 3 & 0,762 & Valid \\
\hline & 4 & 0,612 & Valid \\
\hline & 5 & 0,458 & Valid \\
\hline & 6 & 0,665 & Valid \\
\hline & 7 & 0,670 & Valid \\
\hline & 8 & 0,782 & Valid \\
\hline & 9 & 0,752 & Valid \\
\hline & 10 & 0,765 & Valid \\
\hline \multirow{10}{*}{ Z } & 1 & 0,309 & Valid \\
\hline & 2 & 0,838 & Valid \\
\hline & 3 & 0,668 & Valid \\
\hline & 4 & 0,366 & Valid \\
\hline & 5 & 0,699 & Valid \\
\hline & 6 & 0,708 & Valid \\
\hline & 7 & 0,843 & Valid \\
\hline & 8 & 0,715 & Valid \\
\hline & 9 & 0,743 & Valid \\
\hline & 10 & 0,508 & Valid \\
\hline \multirow{2}{*}{$\mathrm{Y}$} & 1 & 0,103 & Valid \\
\hline & 2 & 0,384 & Valid \\
\hline
\end{tabular}


ARTIKEL

\begin{tabular}{|l|l|l|l|}
\hline \multirow{4}{*}{} & 3 & 0,841 & Valid \\
\cline { 2 - 4 } & 4 & 0,684 & Valid \\
\cline { 2 - 4 } & 5 & 0,817 & Valid \\
\cline { 2 - 4 } & 6 & 0,782 & Valid \\
\cline { 2 - 4 } & 7 & 0,628 & Valid \\
\hline
\end{tabular}

Sumber: Data Diolah

Berdasarkan tabel 2, hasil uji validitas terlihat bahwa terdapat 52 pertanyaan yang dinyatakan valid dan terdapat 3 pertanyaan yang tidak valid karena nilai $r$ hitung kurang dari 0,361 . Sehingga 4 pertanyaan yang tidak valid akan dihilangkan dari daftar pertanyaan yang akan disebarkan ke responden untuk pengambilan data. Jadi terdapat 48 pertanyaan yang layak digunakan untuk mengukur indikator dan variabel yang akan diukur.

\section{Uji Realibilitas}

Uji reliabilitas dilakukan terhadap butir pernyataan atau pernyataan yang sudah valid. Untuk melihat reliabilitas masing-masing instrument yang digunakan, penulis menggunakan koefisien Cronbach alpha (a). Suatu instrument dikatakan reliabel jika nilai Cronbach alpha lebih besar dari batasan yang ditentukan yakni 0,6 atau nilai korelasi hasil perhitungan lebih besar daripada nilai dalam tabel dan dapat digunakan untuk penelitian. Hasil uji reliabilitas dalam peneltian ini disajikan dalam tabel berikut:

Tabel 3. Hasil Uji Reliabilitas

\begin{tabular}{|c|c|c|}
\hline Variabel & Cronbach's Alpha & Keterangan \\
\hline Kualitas Produk (X1) & 0,772 & Relaibel \\
\hline Citra Merek (X2) & 0,772 & Reliabel \\
\hline Word of Mouth (X3) & 0,874 & Sangat Reliabel \\
\hline Kepuasan Konsumen (Z) & 0,835 & Sangat Reliabel \\
\hline Minat Beli Ulang (Y) & 0,832 & Sangat Reliabel \\
\hline N of Item & 52 & \\
\hline
\end{tabular}

Sumber: data diolah

Berdasarkan tabel 3, hasil uji reliabilitas dalam penelitian ini diperoleh nilai masingmasing cronbach's alpha dari kualitas produk dan citra merek memiliki nilai cronbach's alpha $>$ 0,60 artinya reliabel. Dan nilai masing-masing cronbach's alpha dari Word of Mouth, kepuasan konsumen dan minat beli ulang memiliki nilai cronbach's alpha $>0,80$ artinya sangat reliabel.

\section{Analisis Jalur}

Dalam penelitian ini, Path Analysis digunakan untuk hubungan secara langsung dan tidak langsung kualitas produk, citra merek, Word of Mouth terhadap minat beli ulang melalui kepuasan konsumen sebagai variabel intervening. Hasil analsis jalur dalam penelitian ini disajikan dalam tabel berikut:

Tabel 4. Hasil Perhitungan Pengaruh

\begin{tabular}{|c|c|c|c|}
\hline Variabel & Pengaruh Langsung & Pengaruh Tidak Langsung & Total Pengaruh \\
\hline $\mathrm{X} 1 \rightarrow \mathrm{Z}$ & 0,320 & - & 0,320 \\
\hline $\mathrm{X} 2 \rightarrow \mathrm{Z}$ & 0,215 & - & 0,215 \\
\hline $\mathrm{X} 3 \rightarrow \mathrm{Z}$ & 0,439 & - & 0,439 \\
\hline $\mathrm{Z} \rightarrow \mathrm{Y}$ & 0,175 & - & 0,175 \\
\hline $\mathrm{X} 1 \rightarrow \mathrm{Y}$ & 0,318 & - & 0,318 \\
\hline $\mathrm{X} 2 \rightarrow \mathrm{Y}$ & 0,155 & - & 0,155 \\
\hline $\mathrm{X} 3 \rightarrow \mathrm{Y}$ & 0,403 & - & 0,403 \\
\hline
\end{tabular}


ARTIKEL

\begin{tabular}{|c|c|c|c|}
\hline $\mathrm{X} 1 \rightarrow \mathrm{Z} \rightarrow \mathrm{Y}$ & 0,320 & 0,128 & 0,448 \\
\hline $\mathrm{X} 2 \rightarrow \mathrm{Z} \rightarrow \mathrm{Y}$ & 0,215 & 0,086 & 0,301 \\
\hline $\mathrm{X} 3 \rightarrow \mathrm{Z} \rightarrow \mathrm{Y}$ & 0,439 & 0,176 & 0,615 \\
\hline
\end{tabular}

Sumber: Data Diolah

Pada tabel 4, model analisis jalur gabungan diatas merupakan analisis jalur keseluruhan dari hasil penelitian yang sudah dilakukan.Sehingga dapat terlihat perbedaan dari model analisis jalur tahap pertama dan model analisis jalur tahap kedua. Analisis jalur tahap pertama Kualitas produk (X1), Citra merek (X2), dan Word of Mouth (X3) terhadap Kepuasan konsumen (Z). Analisis jalur tahap kedua variabel Kualitas produk (X1), Citra merek (X2), Word of Mouth (X3) dan Kepuasan konsumen (Z) terhadap Minat beli ulang (Y).

1. Pengaruh langsung kualitas produk (X1) terhadap Kepuasan konsumen (Z) berdasarkan pada tabel 4 diketahui untuk variabel kualitas produk (X1) berpengaruh positif dan signifikan terhadap Kepuasan konsumen $(Z)$ dengan nilai koefisien sebesar 0,320. Maka Ha diterima dan $\mathrm{HO}$ ditolak dengan tingkat signifikansi 5\% sehingga kesimpulannya secara parsial variabel kualitas produk mempunyai pengaruh positif dan signifikan terhadap minat kepuasan konsumen. Jika dilihat dari hasil skala pengukuran nilai indeks, berdasarkan varibel kualitas produk yang meliputi: memberikan keamanan yang baik untuk pengguna IPhone, kemudahaan dalam menjalankan aplikasi bagi pengguna IPhone, terdapat ciri khas logo di belakang handphone, handphone iPhone masih bisa menyala walaupun terkena hujan, Ketika handphone IPhone hilang bisa dicari melalui Apple ID, handphone IPhone memiliki kapasitas memori yang besar, kamera handphone iPhone memiliki hasil foto yang jernih, pemakaian handphone iPhone dapat digunakan lebih dari 2 tahun, Tersedia call center untuk keluhan konsumen, outlet IPhone tersedia di berbagai daerah di Indonesia, banyak varian warna handphone yang tersedia, tampilan aplikasi yang bisa diubah ubah sesuai tema. Hasil penelitian ini sejalan dengan penelitian yang dilakukan oleh (Puspitasari, 2016) bahwa kualitas produk berpengaruh terhadap kepuasan konsumen dengan kualitas produk yang berkualitas maka keputusan dari banyak konsumen akan berdampak positif dikarenakan kualitas produk memberikan nilai lebih terhadap kepuasan konsumen. Hal ini menunjukkan bahwa penelitian survey responden terhadap kualitas kerja signifikan dalam mempengaruhi kepuasan konsumen.

2. Pengaruh langsung citra merek (X2) terhadap Kepuasan konsumen (Z) berdasarkan pada tabel 4 diketahui untuk variabel citra merek (X2) berpengaruh positif dan signifikan terhadap Kepuasan konsumen $(Z)$ dengan nilai koefisien sebesar 0,215 . Maka Ha diterima dan $\mathrm{H0}$ ditolak dengan tingkat signifikansi 5\% sehingga kesimpulannya secara parsial variabel citra merek mempunyai pengaruh positif dan signifikan terhadap kepuasan konsumen. Jika dilihat dari hasil skala pengukuran nilai indeks, berdasarkan variabel citra merek yang meliputi: Citra merek IPhone sesuai dengan kualitas produk, IPhone memiliki kelas handphone yang berkesan bagi pengguna, Desain handphone IPhone yang tipis, Warna handphone IPhone yang menarik, Dapat digunakan untuk keperluan sehari-hari, Semua kalangan masyarakat bisa menggunakannya, Pembaruhan software setiap saat agar kinerja handphone meningkat dan IPhone memiliki logo yang mudah dikenali. Maka dapat dinilai melalui nilai indeks dengan skala pengukuran nilai indeks tertinggi terdapat pada indikator IPhone memiliki logo yang mudah dikenali. Sedangkan indeks terendah terdapat pada indikator IPhone memiliki kelas handphone yang berkesan bagi pengguna. Hasil penelitian ini sejalan dengan penelitian (Kurniawati et al., 2014), yang menyatakan bahwa variabel citra merek berpengaruh signifikan terhadap kepuasan konsumen. Hal ini menunjukkan bahwa penelitian survey responden terhadap citra merek signifikan dalam mempengaruhi kepuasan konsumen. 
3. Pengaruh langsung Word of Mouth (X3) terhadap Kepuasan konsumen (Z) berdasarkan pada tabel 4 diketahui untuk variabel Word of Mouth (X2) berpengaruh positif dan signifikan terhadap Kepuasan konsumen $(Z)$ dengan nilai koefisien sebesar 0,439 . Maka Ha diterima dan $\mathrm{HO}$ ditolak dengan tingkat signifikansi 5\% sehingga kesimpulannya secara parsial variabel Word of Mouth mempunyai pengaruh positif dan signifikan terhadap minat beli ulang. Jika dilihat dari hasil skala pengukuran nilai indeks, berdasarkan variabel Word of Mouth meliputi pengguna IPhone dapat menyampaikan informasi dengan baik terhadap pengguna baru IPhone, Penguna IPhone berbicara sesuai fakta mengenai produk IPhone, pembicaraan yang menarik untuk didengar bagi pengguna baru IPhone, topik yang dibahas sesuai dengan yang diinginkan, pengguna IPhone memiliki akun media sosial, memiliki alat komunikasi seperti handphone untuk berbicara, keahlian dalam menerima informasi, daya tarik lawan bicara, informasi yang didapatkan dapat berpengaruh positif dan objektivitas lawan bicara. Hasil penelitian ini sejalan dengan penelitian yang dilakukan (Nugraha et al., 2015) yang menyatakan bahwa variabel Word of Mouth berpengaruh signifikan terhadap variabel kepuasan konsumen. Hal ini menunjukkan bahwa penelitian survey responden terhadap Word of Mouth signifikan mempengaruhi kepuasan konsumen.

4. Pengaruh langsung kualitas produk (X1) terhadap minat beli ulang (Y) berdasarkan pada tabel 4 diketahui untuk variabel kualitas produk (X1) berpengaruh positif dan signifikan terhadap minat beli ulang (Y) dengan nilai koefisien sebesar 0,175. Maka Ha diterima dan $\mathrm{H} 0$ ditolak dengan tingkat signifikansi 5\% sehingga kesimpulannya secara parsial variabel kualitas produk mempunyai pengaruh positif dan signifikan terhadap minat beli ulang. Hal ini membuktikan bahwa suatu produk seluler yang memiliki call center untuk menerima keluhan konsumen dapat meningkatkan rasa senang begitu juga dengan desain suatu handphone yang elegan dapat meningkatkan kesenangan bagi konsumen sehingga jika konsumen merasa senang akan suatu produk dapat meningkatkan minat beli ulang. Hasil penelitian ini sejalan dengan penelitian yang dilakukan (Sulistyari \& Yoestini, 2012) yang menunjukkan hasil bahwa kualitas produk berpengaruh positif dan signifikan terhadap minat beli ulang.

5. Pengaruh langsung citra merek (X2) terhadap minat beli ulang (Y) berdasarkan pada tabel 4 diketahui untuk variabel citra merek (X2) berpengaruh positif dan signifikan terhadap minat beli ulang (Y) dengan nilai koefisien sebesar 0,318. Maka Ha diterima dan $\mathrm{H0}$ ditolak dengan tingkat signifikansi 5\% sehingga kesimpulannya secara parsial variabel citra merek mempunyai pengaruh positif dan signifikan terhadap minat beli ulang. Hasil penelitian ini membuktikan bahwa citra merek memiliki pengaruh positif dan signifikan terhadap minat beli ulang pada mahasiswa fakultas ekonomi Universitas Esa Unggul. Artinya, citra merek akan berpengaruh terhadap minat beli ulang. Citra merek yang baik dimata konsumen akan meningkatkan minat beli ulang pada suatu produk. Berdasarkan hasil skala pengukuran nilai indeks, memberikan keamanan yang baik untuk pengguna IPhone, kemudahaan dalam menjalankan aplikasi bagi pengguna IPhone, Terdapat ciri khas logo di belakang handphone. Hasil penelitian ini sejalan dengan penelitian yang dilakukan oleh (Prawira \& Yasa, 2014), yang menunjukan bahwa citra merek berpengaruh positif dan signifikan terhadap variabel minat beli yang berarti semakin baik citra merek yang dimiliki maka semakin tinggi minat beli.

6. Pengaruh langsung Word of Mouth (X3) terhadap minat beli ulang (Y) berdasarkan pada tabel 4 diketahui untuk variabel Word of Mouth (X3) berpengaruh positif dan signifikan terhadap minat beli ulang (Y) dengan nilai koefisien sebesar 0,155. Maka Ha diterima dan $\mathrm{H0}$ ditolak dengan tingkat signifikansi 5\% sehingga kesimpulannya secara parsial variabel Word of Mouth mempunyai pengaruh positif dan signifikan terhadap minat beli ulang. Jika dilihat dari hasil skala pengukuran nilai indeks, Pengguna IPhone 
dapat menyampaikan informasi dengan baik terhadap pengguna baru IPhone, Penguna IPhone Berbicara sesuai fakta mengenai produk IPhone, Pembicaraan yang menarik untuk didengar bagi pengguna baru IPhone, Topik yang dibahas sesuai dengan yang diinginkan, Pengguna IPhone memiliki akun media sosial, memiliki alat komunikasi seperti handphone untuk berbicara, keahlian dalam menerima informasi, Daya tarik lawan bicara, Informasi yang didapatkan dapat berpengaruh positif dan Objektivitas lawan bicara, nilai indeks tertinggi adalah memiliki alat komunikasi seperti handphone untuk berbicara. Sedangkan indeks terendah terdapat pada Informasi yang didapatkan dapat berpengaruh positif. Hasil penelitian ini sejalan dengan penelitian (Winajarko, 2014) bahwa Word of Mouth berpengaruh terhadap minat beli.

7. Pengaruh langsung Kepuasan konsumen (Z) terhadap minat beli ulang (Y) berdasarkan pada tabel 4 diketahui untuk variabel Kepuasan konsumen $(Z)$ berpengaruh positif dan signifikan terhadap minat beli ulang (Y) dengan nilai koefisien sebesar 0,403. Maka Ha diterima dan $\mathrm{H} 0$ ditolak dengan tingkat signifikansi 5\% sehingga kesimpulannya secara parsial variabel kepuasan konsumen mempunyai pengaruh positif dan signifikan terhadap minat beli ulang. Jika dilihat dari hasil skala pengukuran nilai indeks, berdasarkan variabel kepuasan konsumen seperti Membeli produk iPhone jika ada keluaran baru, Pendapat positif dari pengguna iPhone, Kualitas iPhone sudah terbukti baik, Tetap memakai karena produk disukai, Tetap membeli karena produk sesuai dengan keinginan, Membeli produk tipe IPhone terbaru, Membeli IPhone dengan warna berbeda, Memberikan informasi produk iPhone kepada orang lain dan Pelanggan IPhone menawarkan orang lain untuk membeli produk iPhone memiliki pengaruh signifikan terhadap minat beli ulang. Indeks tertinggi terdapat pada Kualitas iPhone sudah terbukti baik. Sedangkan indeks terendah terdapat pada indikator Tetap membeli karena produk sesuai dengan keinginan. Hasil penelitian ini sejalan dengan penelitian yang dilakukan oleh (Widyartini \& Purbawati, 2019) yang menunjukan bahwa customer satisfaction (kepuasan konsumen) berpengaruh positif dan signifikan tehadap repurchase intention (minat beli ulang) dalam hal ini apabila konsumen merasa puas terhadap suatu produk yang digunakan atau dikonsumsi maka akan timbul juga niat untuk membeli ulang pada produk tersebut.

8. Pengaruh tidak langsung kualitas produk (X1) terhadap minat beli ulang (Y) melalui Kepuasan konsumen $(\mathrm{Z})$ dilakukan dengan cara mengkalikan nilai koefisien tidak langsungnya yaitu $0,320 \times 0,403=0,128$, atau lebih kecil dibandingkan pengaruh langsung yaitu sebesar 0,175 , dengan demikian hipotesis ditolak, karena kepuasan konsumen tidak bisa menjadi variabel mediasi. Penelitian ini tidak berhasil membuktikan hipotesis kedelapan yang menyatakan bahwa kualitas produk berpengaruh terhadap minat beli ulang yang dimediasi kepuasan konsumen pada mahasiswa fakultas ekonomi Universitas Esa Unggul. Artinya untuk menimbulkan minat beli ulang suatu produk bisa langsung dilihat kualitas dari suatu produk tersebut tanpa konsumen harus merasa puas. Hasil penelitian ini sejalan dengan penelitian yang dilakukan oleh (Indiarti, 2020) yang menunjukan bahwa kepuasan tidak memediasi antara kualitas produk terhadap minat beli ulang.

9. Pengaruh tidak langsung citra merek (X2) terhadap minat beli ulang (Y) melalui Kepuasan konsumen (Z) dilakukan dengan cara mengkalikan nilai koefisien tidak langsungnya yaitu $0,215 \times 0,403=0,086$, atau lebih kecil dibandingkan pengaruh langsung yaitu sebesar 0,318. Maka Ha ditolak dan H0 diterima dengan tingkat signifikansi 5\% sehingga kesimpulannya variabel kepuasan tidak menjadi variabel mediasi antara citra merek terhadap minat beli ulang. Penelitian ini tidak berhasil membuktikan hipotesis kesembilan yang menyatakan bahwa citra merek berpengaruh terhadap minat beli ulang yang dimediasi kepuasan konsumen pada mahasiswa fakultas 
ekonomi Universitas Esa Unggul. Artinya untuk menimbulkan minat beli ulang suatu produk bisa langsung dilihat dari citra merek tersebut tanpa konsumen harus merasa puas. Hasil penelitian ini sejalan dengan penelitian yang dilakukan oleh (Ramadhan \& Santosa, 2017) yang menunjukan bahwa kepuasan tidak memediasi antara citra merek terhadap minat beli ulang.

10. Pengaruh tidak langsung Word of Mouth (X3) terhadap minat beli ulang (Y) melalui Kepuasan konsumen $(\mathrm{Z})$ dilakukan dengan cara mengkalikan nilai koefisien tidak langsungnya yaitu $0,439 \times 0,403=0,176$, atau lebih besar dibandingkan pengaruh langsung yaitu sebesar 0,155. Maka Ha diterima dan H0 ditolak dengan tingkat signifikansi 5\% sehingga kesimpulannya variabel kepuasan bisa menjadi variabel mediasi antara Word of Mouth terhadap minat beli ulang. Penelitian ini berhasil membuktikan hipotesis kesepuluh yang menyatakan bahwa Word of Mouth berpengaruh terhadap minat beli ulang yang dimediasi kepuasan konsumen pada mahasiswa fakultas ekonomi Universitas Esa Unggul. Artinya untuk menimbulkan minat beli ulang suatu produk konsumen harus merasa puas terlebih dahulu yang disebabkan oleh Word of Mouth yang sudah sesuai keinginan.

\section{E. KESIMPULAN}

Berdasarkan hasil penelitian dapat ditarik beberapa kesimpulan sebagai berikut: 1) Variabel Kualitas Produk, Citra Merek, Word of Mouth, berpengaruh positif dan signifikan terhadap kepuasan konsumen pada mahasiswa fakultas ekonomi Universitas Esa Unggul; 2) Variabel Kualitas Produk, Citra Merek, Word of Mouth, dan Kepuasan Konsumen berpengaruh positif dan signifikan terhadap minat beli ulang pada mahasiswa fakultas ekonomi Universitas Esa Unggul; 3) Variabel Kualitas Produk dan Citra Merek mempunyai pengaruh positif dan signifikan terhadap minat beli ulang tetapi kepuasan konsumen tidak memediasi; dan 4) Variabel Word of Mouth mempunyai pengaruh positif dan signifikan terhadap minat beli ulang dengan mediasi kepuasan konsumen.

\section{DAFTAR PUSTAKA}

Aghniyah, K. F. (2019). Pengaruh Lokasi dan Word of Mounth (WOM) Terhadap Keputusan Pembelian (Survei Pada Kopi EUY! Coffe Shop).

Amstrong, \& Keller. (2015). Marketing an Introducing Prentice Hall. Pearson Education, Inc. Aries, M., Sunarti, \& Mawardi, M. K. (2018). Pengaruh Word Of mouth terhadap minat beli serta dampaknya pada keputusan pembelian (Survei Pada Make up Artist yang Membeli dan Menggunakan Produk KRYOLAN di Kabupaten Bojonegoro). Jurnal Administrasi Bisnis, 60(3), 36-44.

Assael, H. (2004). Consumen Behaviour And Marketing Action.

Augusty, F. (2006). Metode Penelitian Manajemen: Pedoman Penelitian untuk skripsi, Tesis dan Disertai Ilmu Manajemen. Semarang: Universitas Diponegoro.

Basyar, K., \& Sanaji, S. (2018). Pengaruh Persepsi Kemudahan dan Persepsi Manfaat Terhadap Niat Beli Ulang Secara Online dengan Kepuasan sebagai Variabel Intervening. BISMA (Bisnis Dan Manajemen), 8(2), 204. https://doi.org/10.26740/bisma.v8n2.p204-217

c. Mowen, J., \& Minor, M. (2002). Perilaku Konsumen. Erlangga.

Denniswara, E. P. (2016). Pengaruh Kualitas Produk, Harga dan Promosi terhadap Intensi Membeli Ulang Produk My IDEAS. 1(4), 480-488.

Fahima, L. (2007). Word of Mouth Kalahkan Pengaruh Iklan.

Ghozali, I. (2006). Aplikasi Analisis Multivariate Dengan Program SPSS. Badan Penerbit Universitas Diponegoro.

Ghozali, I. (2018). Aplikasi Analisis Multivariative dengan Program IBM SPSS (25th ed.). 
Universitas Diponegoro.

Griffin, W. R., \& Elbert, R. J. (2002). Manajemen Bisnis. Erlangga.

Hasan, A. (2014). Marketing dan Kasus-Kasus Pilihan. CAPS.

Hasan, A. (2018). Marketing Dan Kasus-Kasus Pilihan (Cetakan Pe). Media Pressdindo.

Indiarti, T. (2020). Pengaruh Kualitas Produk Dan Kualitas Pelayanan Terhadap Minat Beli Ulang Dengan Kepuasan Pelanggan Sebagai Variabel Mediasi (Studi Kasus Pelanggan Coklat Cafe Yogyakarta).

International Data Corporation. (2019). Market Share Smartphone 2019. International Data Corporation.

Irawan. (2019). 10 Prinsip Kepuasan Pelanggan. Elex Media Komputindo.

Irawan, D., \& Japarianto, E. (2013). Analisis Pengaruh Kualitas Produk Terhadap Loyalitas Melalui Kepuasan Sebagai Variabel Intervening Pada Pelanggan Restoran Por Kee Surabaya. 1(2), 1-8.

Juniwati. (2015). Pengaruh Perceived Ease of Use, Enjoyment dan Trust Terhadap Repurchase Intention dengan Customer Satisfaction Sebagai Intervening pada Belanja Online (Studi Pada Mahasiswa Universitas Tanjungpura Pontianak). Jurnal Ekonomi Bisnis Dan Kewirausahaan, 4(1), 140. https://doi.org/10.26418/jebik.v4i1.11465

Kotler, \& Keller. (2012). Manajemen Pemasaran. Jakarta: Erlangga.

Kotler, \& Keller. (2014). Manajemen Pemasaran. Jakarta: Erlangga.

Kotler, Philip, \& Amstrong, G. (2014). Principles of Marketing. Jakarta: Erlangga.

Kotler, Philip, \& Keller. (2007). Manajemen Pemasaran. Indeks.

Kotler, Phillip, \& Keller. (2009). Manajemen Pemasaran. Jakarta: Erlangga.

Kurniawati, D., Suharyono, \& Kusumawati, A. (2014). Kepuasan dan Loyalitas Pelanggan (Studi Pada Pelanggan KFC Cabang Kawi Malang). 14(2), 1-9.

Kusdyah, I. (2012). Persepsi Harga, Persepsi Merek, Persepsi Nilai, dan Keinginan Pembelian Ulang jasa Klinik Kesehatan. Jurnal Manajemen Pemasaran, 7(1), 25-32. https://doi.org/10.9744/pemasaran.7.4.25-32

Lenzun, J. J., Massie, J. D. D., \& Adare, D. (2014). Pengaruh kualitas produk, harga dan promosi terhadap kepuasan pelanggan kartu prabayar telkomsel. 2(3), 1237-1245.

Maghfiroh, K. (2019). Pengaruh Harga, Kualitas Produk dan Word of Mouth Terhadap Kepuasan Konsumen Serta Implikasinya pada Keputusan Pembelian Smartphone Xiaomi. Business Management Analysis Journal (BMAJ), 2(2). https://doi.org/10.24176/bmaj.v2i2.4075

marketbeat. (2020). Apple earnings estimates and actuals by quarter. Marketbeat.com.

Mulyana, A. (2019). Influence of Product Quality adn Service Quality on Shao Kao Kertajaya Customer Repurchase Interest through Customer Satisfactionri. Agora, 7(2).

Nela, F., \& Hakim, L. (2015). Analisis Pengaruh Harga, Citra Merek dan Kualitas Produk terhadap Loyalitas Pengguna Smartphone Samsung di STIE Totalwin Semarang. Among Makarti, 8(15), 94-107.

Nugraha, F. A. A., Suharyono, S., \& Kusumawati, A. (2015). Pengaruh Word Of Mouth Terhadap Keputusan Pembelian dan Kepuasan Konsumen (Studi Pada Konsumen Kober Mie Setan Jalan Simpang Soekarno-Hatta Nomor 1-2 Malang). Jurnal Administrasi Bisnis (JAB), 22(1), 1-7.

Palma, M. A., \& Andjarwati, A. L. (2016). Pengaruh Kualitas Produk, Kemudahan, Dan Harga Terhadap Niat Beli Ulang Dengan Kepuasan Sebagai Variabel Intervening (Studi Pada Pelanggan Produk Fashion Melalui Toko Online di Surabaya). Jurnal Riset Ekonomi dan Manajemen, 16(1), 84. https://doi.org/10.17970/jrem.16.60106.id

Prasetya, W., Yulius, C., Industri, P. T., Teknik, F., \& Jaya, U. A. (2017). Pengaruh Kualitas Produk dan Citra Merek Terhadap Kepuasan Konsumen dan Minat Beli Ulang: Studi Pada Produk EATLAH. 92-100. 
Prastiwi, E. (2016). Pengaruh Nilai, Harga, Kualitas Produk Dan Kualitas Pelayanan Terhadap Kepuasan Konsumen dan Loyalitas Konsumen Studi Kasus Pada Waroeng Spesial Sambal Yogyakarta.

Prawira, B., \& Yasa, N. (2014). Pengaruh Kualitas Produk, Citra Merek dan Persepsi Harga Terhadap Minat Beli Produk Smartphone Samsung di Kota Denpasar. E-Jurnal Manajemen Universitas Udayana, 3(12), 253856.

Pujadi, B. (2010). Studi Tentang Pengaruh Citra Merek Terhadap Minat Beli Melalui Sikap Terhadap Merek. Jurnal Sains Pemasaran Indonesia (Indonesian Journal of Marketing Science), Vol. 9, 59-76.

Puspasari, A. (2014). Pengaruh Kualitas Produk Terhadap Word of Mouth Melalui Kepuasan Pelanggan. Jurnal Ilmu Manajemen, 2(4), 1737-1748.

Puspitasari, L. (2016). Pengaruh Kualitas Produk dan Kualitas Pelayanan Terhadap Kepuasan Pelanggan.

Ramadhan, A. G., \& Santosa, S. B. (2017). Analisis Pengaruh Kualitas Produk, Kualitas Pelayanan, dan Citra Merek terhadap Minat Beli Ulang pada Sepatu Nike Running di Semarang melalui Kepuasan Pelanggan sebagai Variabel Intervening. 6, 1-12.

Sari, H. P. (2016). Pengaruh Citra Merek, Fitur, Desain dan Persepsi Harga Terhadap Keputusan Pembelian Smartphone Xiaomi. Jurnal Perspektif, 25, 1-18.

Savitri, I. A. P. D., \& Wardana, I. M. (2018). Pengaruh Citra Merek, Kualitas Produk dan Persepsi Harga Terhadap Kepuasan dan Niat Beli Ulang. E-Jurnal Manajemen Universitas Udayana, 7(10). https://doi.org/10.24843/ejmunud.2018.v07.i10.p19

Sernovitz, A. (2014). Word of Mouth Marketing How Smart Companies Get People Talking. Greenleaf Book Group Press Austin.

Sinurat, E. S. M., Lumanauw, B., \& Roring, F. (2017). Pengaruh Inovasi Produk, Harga, Citra Merek Dan Kualitas Pelayanan Terhadap Loyalitas Pelanggan Mobil Suzuki Ertiga. Jurnal EMBA: Jurnal Riset Ekonomi, Manajemen, Bisnis Dan Akuntansi, 5(2), 22302239. https://doi.org/10.35794/emba.v5i2.16522

Sugiyono. (2011). Metode Penelitian Kuantitatif, Kualitatif dan R\&D. Bandung: Alfabeta.

Sugiyono. (2016). Metode Penelitian Kuantitatif, Kualitatif dan R\&D. Bandung: Alfabeta.

Sujarweni, V. W. (2014). Metode Penelitian: Lengkap, Praktis, dan Mudah Dipahami. Pustaka Baru Press.

Sulistyari, I. N., \& Yoestini. (2012). Analisis Pengaruh Citra Merek, Kualitas Produk, Dan Harga Terhadap Minat Beli Produk Oriflame (Studi Kasus Mahasiswi Fakultas Ekonomika dan Bisnis Jurusan Manajemen Universitas Diponogoro Semarang), 1, 117.

Sumardi. (2009). Word of Mouth Marketing, Fans dan Peluang Tumbuh.

Sumarwan, U. (2011). Perilaku Konsumen Teori dan Penerapannya dalam Pemasaran. Ghalia Indonesia.

Tjiptono, F. (2012). Strategi Pemasaran. Yogyakarta: Andi Offset.

Tjiptono, F. (2015a). Strategi Pemasaran. Yogyakarta: Andi Offset.

Tjiptono, F. (2015b). Strategi Pemasaran. Jakarta: Gramedia Pustaka Utama.

Umar, H. (2005). Riset Pemasaran dan Perilaku Konsumen. Jakarta: Gramedia Pustaka Utama. Walukow. (2014). Pengaruh Kualitas Produk, Harga, Promosi dan Lokasi Terhadap Keputusan Pembelian Konsumen di Benefenan Centre Sonder Minahasa. EMBA, 2(3).

Waskita, A. I., \& Yuniati, T. (2016). Pengaruh Citra Merek, Harga dan Promosi Terhadap Loyalitas Konsumen. Jurnal Ilmu dan Riset Manajemen, 5(9).

Widyartini, A. A., \& Purbawati, D. (2019). Pengaruh Service Quality dan Price Terhadap Repurchase Intention dengan Customer Satisfaction Sebagai Variabel Intervening Pada Konsumen E-Commerce Elevenia.Co.Id di Kota Semarang. Jurnal Ilmu Administrasi Bisnis, 8(1), 1-11. 
Winajarko, J. (2014). Pengaruh Word of Mouth Terhadap Minat Beli Konsumen Pada Smartphone Blackberry.

Yonita, T., \& Budiono, H. (2020). Pengaruh Ewom Terhadap Brand Image dan Purchase Intention Produk Innisfree di Jakarta. Jurnal Manajerial Dan Kewirausahaan, 2(1), $152-161$. 